Wiestaw Plywaczewski

\title{
ORGANISED TRAFFICKING IN PROTECTED SPECIES OF WILD FLORA AND FAUNA AS A MEANS OF SUPPORTING ARMED CONFLICTS AND TERRORISM
}

\section{Wildlife crime: an introduction}

Following in the wake of 9/11, anti-terrorist agencies in several countries blocked the bank accounts of numerous organizations suspected of terrorist activity or of supporting terrorism in some way. One outcome of this operation was that rebel groups and terrorist organizations immediately turned their attention to seeking new sources of income from which to fund their activities. ${ }^{1}$ Crime targeted at natural environmental resources was an area which, at that time, lay beyond the interest of those fighting terrorism. In the global map of crime, poaching was recognized as a dangerous phenomenon as early as the 19th century but it was not until the 1980s that the intensification, scale and dynamism of this particular crime - together with its political entanglements - attracted serious attention. Thus today, we are dealing with a phenomenon the statistical image of which is both incomplete and far from clear. Most of those organizations charged with the responsibility of addressing the issue, stress that crimes against nature may be considered on a par with those of organized drug trafficking and the illegal arms trade. One thing of which there is no doubt, is that the latter two areas of criminal activity are interlinked with the illegal trade in endangered species of flora and fauna. It is also clear that such natural resources are being exploited to fund armed organizations who conduct terrorist activities in support of dictatorial regimes in a number of geographical locations around the world.

In some African, Southeast Asian and South American countries, funding is also being raised by granting licences or concessions to large industrial corporations terroryzmu w ujęciu regulacji międzynarodowych, [in:] E.W. Pływaczewski (ed.), Aktualne problemy prawa karnego i kryminologii, Białystok 2005, pp. 25-46. 
for the exploitation of tropical forests. This has been going on for decades and has resulted in huge swathes of land being deforested. Hitherto, deforestation on this scale was primarily a dictate of warfare where deforestation was used to clear battlefields or to deny the enemy the use of strategic materials, or both. An example of such activity was the clearing of the primeval forests in the Białowieża region of Poland by the German military administration during World War I. ${ }^{2}$ In more recent history, conflicts, both global and localized, have continued to reap devastation on the world's forestry resources. During the war in Indochina for example, in pursuing the "scorched earth" doctrine and using chemical defoliants, America laid waste to large areas of tropical rainforest in the territories of Vietnam, Laos and Cambodia, the purpose of which was to deny protective cover to North Vietnamese forces moving men and supplies into South Vietnam. ${ }^{3}$ It is not difficult to appreciate that along with the destruction of the forested areas concerned, the species of wildlife that inhabited those regions, some of them valuable, would also have perished. It is also worth mentioning that innocent people fall victim to war games of this nature, too. The effect of that destruction on the Indochinese Peninsular is still visible today - the chemicals used in the defoliants having being designed to work over a long period of time.

\section{The Plundering of Flora and Fauna from the standpoint of UNODC operations}

In the arena of environmental protection, particularly with regard to the protection of species of wild flora and fauna, the extremely efficient actions undertaken by the United Nations Office on Drugs and Crime (UNODC), calls for being both recognized and appreciated. ${ }^{4}$ It is worth noting that a long time ago the UNODC experts dealing with wildlife crime linked the phenomenon with the activities of organized international criminal structures involved in drug production and distribution, money laundering, deception, arms trafficking and the like. That such relationship exists is evidenced in reports prepared both by UNODC and those organizations with whom it collaborates. Such reports also make reference to the involvement of terrorist organizations and rebel groups. ${ }^{5}$

UNODC data illustrates that in Africa, destruction of the natural environment during armed conflicts between warring nations (including tribal wars) is not an

2 See: S. Kossak, The Białowieża Forest Saga, Muza S.A. p. $42 \mathrm{ff}$.

3 Cf. W. Pływaszewski Międzynarodowa współpraca policyjna w zakresie przeciwdziałania przestępczości związanej z nielegalnym handlem chronionymi gatunkami fauny i fiory, "Przegląd Policyjny" No. 4(100)/2010 pp. 71-93.

4 www.unodc.org/documents/southasia/Newsletter/other/TRAFFIC (info dated June 15, 2010).

5 Cf. C. Nelleman, J. Redmond, J. Refisch, The Last Stand of the Gorilla. Environmental Crime and Conflict in the Congo Basin, United Nations Environmental Programme 2010, p. 25. 
uncommon occurrence. As an example, during the course of the civil war in Uganda, soldiers on both sides committed not only crimes against humanity but also embarked on the mass killing of protected species of wild life - particularly elephant, rhinoceros and gorilla. Elephants were killed for their tusks and rhinoceros for their horn. The money raised from the sale of ivory and rhinoceros horn was subsequently used to buy arms. Gorillas were killed indiscriminately to provide meat for the warring factions. During such hunting raids, large areas of forest were burned in order to drive out the game, destroying or seriously damaging other valuable species of flora and fauna. ${ }^{6}$ Similar actions occurred in Kenya between 1963 and 1967 when the southeastern region of the country became the theatre for war between the Kenyan army and rebel Somali tribes. Both parties to that conflict participated in the mass slaughter of animals and burning of the habitats in which they lived, deeming such actions to be an element of tactical warfare which, among other things, was aimed at destroying the enemy's food base. Although the governments of Kenya and Somalia eventually signed an armistice in 1967, some marauding secessionists found new employment for themselves with poaching gangs - the so-called "shifta'. ${ }^{7}$ These gangs are responsible for having driven to a critical state, the survival of many rare species of animal, especially elephant and rhinoceros.

Today, the shady and unsavoury practice of hunting protected animal species continues driven on by a successive generation of Somali poachers. Indeed, the illicit acquisition of rare species of flora and fauna, not just the valuable parts of protected animals, has become a specialized area of activity for rebel groups operating in the territory of the Congo. UNODC experts firmly believe that the proceeds of such crime are used for the purpose of buying arms. ${ }^{8}$

\section{Protection of mountain gorillas along the eastern frontier of the Democratic Republic of the Congo}

It is particularly notable that the area where the frontiers of the Congo, Uganda and Rwanda adjoin each other has become one of Africa's hotspots, with troops of opposing political affiliation stationed in the region engaging in combat. The National Congress for the Defence of the People - Congres National pour la Défense $\mathrm{du}$ Personnes (CNDP), established by members of the Tutsi tribe, is one such organization and it is estimated that some 4,000 CNDP insurgents are deployed in the area of Wirunga National Park. Their rival and bitter enemy for the past six-decades, are members of the Huta tribe which are gathered around the Democratic Forces

\footnotetext{
Ibidem, p. 25ff.

See: A. Alao, Natural Resources and Conflict in Africa: the Tragedy of Endowment, Rochester 2007, p. 101.

The Last Stand of the Orangutan: State of Emergency: Illegal Logging, Fire and Palm Oil in Indonesia National Park, UNEP 2007, p. $6 \mathrm{ff}$.
} 
for the Liberation of Rwanda - Forcer Démocratiques de Libération du Rwanda (FDLR). The military activity of these two forces is concentrated in an area that ranks as one of the most valuable natural nature reserves worldwide. Armed conflict between the warring tribes came to a head in Rwanda in 1994 when some 800,000 Rwandans (mainly Tutsis) were murdered by the Hutu. Although not appreciated at the time, this act of genocide was to have serious and tragic consequences for the unique natural features appearing in that part of the African continent, for it resulted in more than one-million Rwandans fleeing their native country to seek refuge in the Congo. Most went into refugee camps but the area many others chose was the remote and mainly inaccessible confines of Wirunga National Park and its neighbouring nature reserves, where they established camps and the means to defend themselves. When the Hutu regime was overthrown in Rwanda, another wave of fugitives fled the country. These were the torturers and executioners of the Tutsis who, along with their families feared reprisal from their former victims - they too made for the sanctuary of the parks and that is how the hapless mountain gorilla found itself in the firing line, along with several other species of rare and valuable fauna. Armed combat groups fought each other and conducted their activities over a relatively small area which could not leave the otherwise pristine condition of the local flora and fauna unaffected. Particularly vulnerable were the mountain gorillas whose initial small stock of 380 specimens was ultimately reduced to a critical level as a result of rebel attacks. ${ }^{9}$ Although each party to the conflict officially declared their willingness to protect the habitat of these unique apes', in reality and as independent sources have affirmed, this does not happen. A third force that attempts, at least officially, to alleviate ethnically imbued conflict in this neuralgic area, is the Congolese army. In practice, however, members of the army of the Democratic Republic of the Congo (DRC) - Armée de la République du Congo Démocratique (ARCD) often support FDLR troops which does little to further mutual relations between the forces situated in the Congolese/Rwandan border region.

Defence of the protected species of animals placed under threat is primarily in the hands of guards of the Congolese Nature Protection Service - Institut Congolaise pour la Conservation de la Nature (ICCN), who enjoy sporadic support from UN peacekeeping forces. The "blue helmets" are tasked with the responsibility of stabilizing the situation in the Congolese province of North Kivu but they also participate in operations aimed at taming poachers, rebels or whoever else may be threatening the natural habitat of the mountain gorillas'. These sites, which include large areas of tropical forest, are also at danger from excessive exploitation. Indeed, the unlawful removal of rare species of flora and fauna has risen to become a specialized area of crime for a variety of syndicates cooperating with rebel groups National Geographic (Poland), Special Report, No. 7/2011, pp. 50-67. 
on DRC territory. As before, the proceeds of such crime are mainly used to acquire arms. ${ }^{10}$ The Congo basin as a whole has become an area of special interest to well organized and well armed gangs who trade in the illicit trafficking of protected flora and fauna and who also control the illegal logging of tropical timber. Leaders of local militia tend to enter into informal arrangements with representatives of businesses or consortiums resourcing tropical hardwoods, guaranteeing them protection in their illicit trade in exchange for a suitable payment in forced tribute.

The protection offered by the insurgents is not limited to logging consortia: it also extends to those smuggling a wide variety of other illicit raw materials out of the country. Sporadic attempts by government forces in smashing paramilitary organizations in the east of the DRC have not yielded the results expected, as these organizations take advantage of the strong support afforded by their fellow tribesmen living in transient refugee camps. In the view of those tribesmen, cooperation with the militias offer the only opportunity to improve their tragic fate. Suffice it to say that in the Congolese city of Goma, which has become the main hub for refugees, the camps are at present home to over 800,000 people. It is from these camps that the local militias recruit workers for forest clearing, collecting further tributes from entrepreneurs in the process. One other important fact which has to be taken into consideration is that, in Africa, charcoal is the primary source of cooking and heating fuel. The Wirunga National Park buffer zone presently accommodates some 100,000 families and the demand for charcoal amounts to 4,000 bags per day. What this means is that, in order to protect their national parks from devastation, the authorities of the DRC and those of neighbouring countries (Uganda, Rwanda, Kenya), must take immediate action to ensure that this essential commodity is provided on a regular and sustainable basis. Alternative sources of fuel stock promoted by "green" organizations may in the near future serve to avoid irreparable damage to natural habitats, thus saving rare species of flora and fauna from the threat of extinction. For example, the World Wildlife Fund for Nature (WWF) supports the planting of eucalyptus trees around national parks. This solution was successfully adopted in Ethiopia some time ago and it effectively rescued Addis Ababa - population circa eight-million - from a chronic energy shortage. Another initiative, which is winning financial support from a number of international organizations and the DRC government, is the launch of kitchen ranges and increased-capacity stoves fired by butane or by processed blocks of grass or sawdust. 


\section{Protection of flora and fauna versus the activities of drug cartels and paramilitary organizations in South America}

As emphasized earlier, the illegal clearing of tropical forests is involving, to an increasing degree, the drug processing and distribution sector. Some SouthAmerican countries (Columbia, Brazil, Peru) see their valuable rainforests being depleted by the slash-and-burn practice of farmers clearing land for agriculture, not for the production of foodstuffs but for the cultivation of poppy-seed and coca. With the support of U.S. experts, the Colombian government endeavours to locate and destroy these illicit crops which results in the farmers being pushed further and further into the heart of the jungle. This is how increasingly large and valuable areas of rainforest are being destroyed by illegal farmers cultivating illegal crops. ${ }^{11}$ Many of the drug processing and distribution facilities run by the so-called Colombian cartels, are also concealed deep in the forests and this too exposes the areas in which they are located to the destructive actions of the criminal gangs operating them. Another damaging feature of these hidden facilities, is that if they become known to government forces, which is not an infrequent occurrence, they are immediately incinerated to destroy evidence. As a result of this action, large areas of forest are destroyed and many rare species of flora and fauna die out. ${ }^{12}$ From the foregoing it may be safely concluded that the illegal clearing of tropical forests is often associated with the production and distribution of drugs. Cultivating coca - the source of cocaine - has significantly accelerated devastation of the Colombian and Peruvian rainforests and placed under threat the regions biodiversity hotspots. Data acquired by scientists at Stony Brook University, record that the pace of deforestation has increased over the past twenty years even though population growth has slowed and the economy has moved away from traditional agriculture to other sources of revenue income. ${ }^{13}$ Conversely, cultivation of coca has clearly grown with $75 \%$ of world production coming from Colombia in 2000. Earlier scientific reports indicated that the impact of coca cultivation on deforestation was small with (by 2005) as little as $150 \mathrm{sq}$. km. of forest being annually given over to coca farming. ${ }^{14}$ It needs

See: F.E. Thoumi, El imperio de la Droga: Narcotrafico, ekonmia y sociedad an los Andes, Planeta, Bogota 2002; idem, Illicit drugs in the Andes five years after UNGASS-98, [in:] Global Organized Crime. Trends and Developments, ed. by D. Singel, H. van de Bunt and D. Zaitch, Dordrecht-Boston-London, 2003, pp. 33-45; also, Bastos F. Pinkusfeld, The Colombian Puzzle: drugs, society, and human rights. "The International Journal of Drug Policy", Volume 16, Issue 2, pp. 132-133.

12 Cf. B. Hołyst, Kryminologia (10th [Anniversary] Edition), Warszawa 2009, p.300ff. also, see: W. Pływaczewski, Przeciwdziałanie nielegalnej eksploatacji lasów pierwotnych, "Przegląd Policyjny", 2011 (forthcoming). http://pubs.acs.org/doi/abs/10.1021/es102373d. The year 2011 has nonetheless see a disturbingly increasing number of illegal clearing sof primeval forests In Brazil. It is believed that this has occurred owing to the announced amnesty for those who committed acts against valuable fauna prior to entry-into-force of a new law banning the clearing of natural forests. Farmers and their principals, i.e. owners of sawmills and other firms dealing with the clearing and distribution of wood try to 'catch up for the time' by sourcing as much timber as possible before the new regulations come in. The novel law offers radically severer penalties for illegal clearing of protected trees.

$14 \mathrm{http} / / /$ www.sciencedaily.com/releases/2011/01/110128144723 (info dated January 12, 2011). 
to be remembered, however, that $10 \%$ of all known plant and animal species are contained within the world's tropical forests and deforestation to any degree can significantly impact on biodiversity. Subsequent analysis of land use data, also indicates that a forest close to newly developed coca farms was likely to be cut, as was land in areas where the majority of farmland was given over to coca cultivation. Scientists have also identified that local population density linked with weak rural development also impacts on deforestation.

The criminal gangs and organizations who plunder flora and fauna or who otherwise use the rainforests for their illicit activities, include the Colombian drug cartels and the various revolutionary paramilitary groups with whom they are associated. Armed conflict has been going on in Colombia for many years. It involves on the one side government forces and on the other left and right-wing guerilla paramilitary organizations, and - the drug syndicates. This has severely debilitated the authority of the state's constitutional bodies and authorities for which Colombia has suffered a long-standing political and moral crisis. The "bosses" of the Medellin and Cali drug cartels - the like of Carlos Enrique Lehder Rias, Gilberto Orejuela and Pablo Escobar-Gavira, who are known to have commissioned the assassination of government officials and police and military commanders alike have grown to become influential personages in Colombia, with Mr. Escobar even being elected as an MP in 1982, albeit a mandate he was later forced to waive. As he feared denunciation and deportation to the U.S., Escobar accepted terms of isolation negotiated with the Columbian government. The prison in which he dwells - reminiscent of a luxury hotel replete with swimming pool, casino and sports field became in reality a new management centre for his drug trafficking business.

Many of the drug bosses (narcotraficantes or "narcos" as they are more commonly known), such as Lehder, have directly cooperated with paramilitary forces. The attack on the Supreme Court building in Bogotá in 1985 and consequent destruction of court files (including those containing material charging drug cartel leaders) serves as evidence to such liaisons. ${ }^{15}$ Blackmail and abduction are the means typically adopted by revolutionary and criminal organizations to neutralize or eliminate political opposition. In Colombia, abduction is normally carried out by criminal gangs, to include the drug cartels, or by paramilitary forces; either for the reasons aforementioned or for ransom. At their present stage of activity, these organizations resemble classic quasi-terrorist structures albeit without the same motives or methods usually associated with so-called criminal terror. ${ }^{16}$ Among the

15 See: F.E. Thoumi, El Imperio de la Droga..., pp. 33-34.

16 Cf. W. Pływaczewski, Terror kryminalny - nowe zjawiko w obszarze badań kryminologicznych, [in:] A. Bulsiewicz, A. Marek, V. Kwiatkowska-Darul (ed.), Doctrina multiples, veritas una, Toruń 2004, pp. 383-390; also see: J. Świerczewski, M. Hausman, Kryminologiczno-wiktymologiczne aspekty uprowadzenia osób w celu wymuszenia okupu. Raport z badań, “Przegląd Policyjny” No. 2(78)/2005, p. 61. 
insurgent forces, the largest number of abductions goes doubtlessly to the credit of the leftist Revolutionary Armed Forces - Fuerzas Armada Revolucionarias de Colombia (FARC), the United Self-Defence Forces - Ab Urbe Condita (AUC), and the National Liberation Army - Ejercito Liberation Nacional (ELN). The activities of these paramilitary organizations assures us that in the realities of SouthAmerica, political objectives are often interrelated with typical criminal activity. It also appears that kidnapping (with some 3,000 victims annually) along with gains from the narcotics business, is one of the most important sources of funding for these organizations. In 2003 alone, the FARC abducted a total of 673 people including: civil servants (high-ranking state or local government officials, members of the judicature, police and military officers), politicians (including congressmen), clergymen, representatives of foreign diplomatic outposts or foreign businesses, or family members of any of the foregoing (including children). The total number of aliens abducted in Colombia in the years 1995-2000 amounted to $408 .{ }^{17}$

\section{Diamond mining versus terrorist and rebel activity}

The mining of conflict diamonds (the so-called "blood diamonds") is perhaps the most criminogenic activity to be associated with the African continent. For several African dictators, diamond mines have been, and still are, a source of funding to combat political opponents. It is also from this source that the means originate to fund rebellion, crime and terrorist activity. ${ }^{18}$ These strict relationships are confirmed in the biography of Charles Taylor, former president of Liberia, who was put before the UN-backed Special Court for Sierra Leone in 2006. Among the seventeen charges classified as instances of war crime or homicide, the indictment enumerated acts consisting of pillage of valuable natural resources (timber) and trafficking in conflict diamonds to source funding with which to fight political opponents. ${ }^{19}$ Charles Taylor's criminal activity is no exception as it is but one of the numerous examples of how power is utilized by modern dictators in fighting political opposition. The circle of those suspected of trading illicit diamonds has been joined by the Russian, Viktor Bout - today, a renowned arms trader. ${ }^{20}$ Bout was arrested in 2008 in Bangkok, Thailand, following a "sting" operation set up by agents of the Drug Enforcement Agency (DEA). The numerous charges put forth by U.S. law enforcement agencies included the attempted sale of arms to representatives of

17 B. Hołyst, Socjiologia kryminalistyczna, Warszawa 2007, p. $429 f f$.

18 Transnational Organized Crime In the West Africa Region, United Nations Office on Drugs and Crime 2005, p. 27.

19 See: P. Milik, Geneza Specjalnego Trybunału Organizacji Narodów Zjednoczonych dla Sierra Leone. "Prokuratura i Prawo", No. 4/2011, p. $123 \mathrm{ff}$.

20 The feature movie Lord of War, starring Nicholas Cage, was made in 2005 based on the biography of Viktor Bout. 
FARC ${ }^{21}$ It is to be reminded that FARC is listed by the U.S. government as a terrorist organization.

It is no secret that many diamond deposits are located either in or close to areas of significant ecological value. When they are mined primeval forests or savannah are damaged or destroyed and valuable species of flora and fauna are annihilated. Those members of local tribes who resist such devastating projects, find themselves confronted by paramilitaries who subject them first to intimidation and if that fails, to elimination. Activists from international ecological organizations are also subject to the same treatment. ${ }^{22}$ The perpetrators are difficult to identify as they are protected by top-ranking government representative who support the interests of large transnational consortia in return for personal gain.

\section{Private military businesses}

Large business concerns which make use of natural resources situated in politically and economically unstable countries, invariably employ specialist companies to look after their security. Officially the services provided by such companies is limited to the protection of installations and/or the provision of personal security but in reality, such firms may also provide a much wider range of services, some of which grossly collide with the law. In the past, private companies of this nature tended to hire former mercenaries who could be used to good effect in creating political instability in a specified African country. An example of such activity was the involvement of mercenaries in a plot to bring about secession in Biafra, a province of the Congo (then, of Zaire) renowned for its considerable natural resources. Another infamous quasi-military operation inspired by an international consortium and local tribal leaders, was the attempt to overthrow the legitimate government of Equatorial Guinea. It ended in fiasco and triggered a worldwide scandal as one of those involved in the putsch was Mark Thatcher, the son of the former UK prime minister. ${ }^{23}$

According to R. Uesseler, private military partnerships and international business consortia - particularly mining consortia - form a shared informal holding structure. As this author notes, these entities "march separately while acting commonly". ${ }^{24}$ It seems that the role of private military businesses is destined to increase in the years

21 D. Farah, and S. Braun, Merchant of Death: Money, Guns, Planes, and the Man Who Makes War Possible, New York 2004.

22 In 1985, Dian Fossey, the internationally known wildlife defender, was killed by poachers. She had for many years researched mountain gorillas in the Rwanda/Congo/Uganda borderland area.

23 R. Uesseler, Wojna jako usługa. Jak prywatne firmy wojskowe niszczą demokracją, Warszarwa 2008, p 211; also see: H. Myrttinen, Alte neue Kriege. Die Privatiesierung der Gewait In Indonesien, [in:] W. Azzelini, Kanzleiter: Das Unternehmen Krieg, p. 212. Ibidem, pp. 129-142. 
to come. Entities such as Executive Outcomes or Pacific Architects and Engineers (PA\&E) build powerful empires, running their businesses across the continents. Although international industrial consortia enjoy the assistance of local militias or insurgent forces, given the increasing rapacity and low credibility of their leaders, these consortia prefer to cooperate with professional partners. Not only do private military agencies offer the best facilities and the best in state-of-the-art equipment: transport, communications and weaponry; they also employ former professional soldiers who are likely to be familiar with the terrain over which they will be required to operate. Such companies also have at their disposal their own intelligence teams whose function, using up-to-date methods of analysis, is to identify and eliminate high-risk situations.

Given the increasingly powerful protests of local communities against the limitless exploitation of their natural resources, the involvement of private armies in ecology-imbued conflicts is expected to grow year-by-year. Already mercenaries are being engaged not just to protect their employers from attack but also to deal with winning a favourable attitude from local communities toward future investments. This is achieved by bribing the leaders of such communities - particularly tribal elders and both central and local government representatives. Those who offer the strongest resistance are intimidated, or - eliminated. The enormous profits assured to these companies by the international consortia who source timber, crude oil, cobalt, copper or diamonds and the like, have caused, and shall continue to cause, the appropriation of ecologically valuable areas of our planet to be an extremely gainful phenomenon. There is no doubt that apart from the official market for natural resources, there is another under development which - aided by a dynamic private military machine - is extremely expansive: the appropriation and pillage of land at the expense of valuable species of flora and fauna. Such dealings increasingly resemble those of organized criminal structures. ${ }^{25}$

\section{Illegal exploitation of primeval forest areas}

Charcoal production is yet another sector controlled by organized gangs including the aforementioned paramilitary forces in the Congo. An estimated $10 \%$ of charcoal supplied on the African continent is legal, the remainder - the so-called "dark figure" - is sourced illegally. What this means is that the basic raw material for charcoal is not being cut from sustainable sources but by clearing virgin forests. Given the growing demand for charcoal the scale of illegal clearings of primeval forests is also increasing, thus leading to uncontrolled destruction of the habitats 
of many unique species of flora and fauna, including rare and much sought-after species of timber.

Data provided by the United Nations Environmental Programme (UNEP), indicates that the predatory exploitation of primeval forests in the Congo basin poses a serious threat to natural habitats of the gorilla. It is estimated that the population level of this great ape will decrease by $90 \%$ by the year $2030 .{ }^{26}$ As WWF data tells us, Liberia and Gabon are facing the most dramatic challenge. Tropical timber is regarded in those countries as a means of raising funds to support warfare. ${ }^{27}$ International ecological organizations confirm that protection of illegal charcoal processing facilities is provided by rebel groups or local militias. Attempts to close down the sites by forest guards, frequently end up in fights in which many of the guards have lost their lives.

As an example, on 24 January 2011, three guards and five of their bearers, were murdered in Wirunga National Park, probably by FDLR rebels. ${ }^{28}$ The ability of the Congolese forest guards to counter the illegal pillage of tropical timber is limited, primarily due to their weak numerical force: with only 650 members in total, it cannot stand up to the insurgents who number many thousands. Their equipment also triggers numerous concerns, all the more so that guard outposts are often attacked by rebels, the guards being disarmed and relieved of their weapons, uniforms and other equipment essential for monitoring the animal habitats they are there to protect. This is further complicated by the complex political situation in the Congo, which favours corruption across all levels of authority. In practice this means that many civil servants - including in numerous cases forest guards - and government soldiers, act in the interests of the timber mafia, with the soldiers often protecting transportation of the stolen material. Timber gangs also tend to enjoy the support of high-ranking military officers. Such officers render indispensable equipment available to the gangs including the trucks used for the transportation of charcoal. Should a convoy such as this be discovered, ICCN forest guards are powerless to detain the offenders as such intervention would place their lives at risk. Hence, when forest guards do intercept and inspect transport suspected of carrying illicit material, more often than not they use the assistance of UN peacekeeping forces: The presence of the peacekeepers dissuades corrupt government soldiers from using their weapons and enables the forest guards to check the vehicles in safety.

26 Cf. The Last Stand of the Gorilla. Environmental Crime and Conflict in the Congo Basin, a report, at: grida.no/ publications/rr/gorilla.

27 W. Pływaczewski, Combating Organized Poaching in Africa: Activities of the Kenya Wildlife Service, [in:] Organized Crime and Terrorism, Reasons - Manifestation - Counteractions, ed. by W. Pływaczewski, Olsztyn 2011, p. $40 \mathrm{ff}$. 


\section{Interpol combats crime against valuable species of flora and fauna}

In September 2010, Interpol launched operation RAMP which targeted the illegal trade in reptiles and amphibians. The operation, which was coordinated by Interpol, extended to 51 countries across five continents and involved wildlife enforcement authorities, including police, customs and specialist units, in each of the participating countries. RAMP resulted in many arrests worldwide and the seizure of thousands of animals and illicit goods valued at EUR 25 million. ${ }^{29}$ The unquestionable success of this operation not only dealt a blow to those trading in rare reptile and amphibian species but also created a model for the future cooperation of national agencies dealing with wildlife protection. RAMP also served to confirm intelligence reports that there was a connection between those involved in the illicit trade in wild flora and fauna, and syndicates involved in drugs and arms trafficking. ${ }^{30}$

An earlier and similar operation coordinated by Interpol - TRAM, took place in February 2009. On this occasion the target was the illegal trade in traditional medicines containing products from protected species of wildlife. It is well known fact that certain plants and animal products provide the main ingredient of many traditional medicines that are claimed to possess qualities for treating a wide variety of ailments. ${ }^{31}$ However, a significant volume of such medicines use raw material obtained in violation of both domestic and international laws. ${ }^{32}$ Experts are of the opinion that the popularity of traditional Asiatic therapies, internationally advertised by the purveyors of such medications, has played a decisive part in the rapid decline of the world's tiger population. Tiger bones are commonly used in the manufacture of agents intended to cure arthritis and muscle atrophy. ${ }^{33} \mathrm{~A}$ similar situation relates to the rhinoceros population - particularly the black Africa rhinoceros and three unique Asian species. The horn of the animal is traditionally used in Chinese medicine for the treatment of fever, convulsions and delirium. It is also claimed to be an effective cure for cancer. ${ }^{34}$ For paramilitary organizations, the trade in animals or their derivative products for use in traditional medicines is an important source of income; it buys weapons, uniforms, communications equipment and transport, as well as rations. Although some rebel leaders in Africa proclaim themselves to be guardians of wildlife, as remarked before, such declarations amount to little more

www.cawtglobal.org/home/2010/11/1/interpol-co-ordinate-operation [...]-info dated November 1, 2010.

See: J. Delaney, Wildlife smuggling Nets Big Bucks for Organized Crime, "The Epoch Times", No. 8/2010; also, see: B. Halstead, Traffic in Flora and Fauna. Trends and Issues in Crime and Criminal Justice, Australian Institute of Criminology, Canberra, No. 41/1992.

These raw materials tend, with increasing frequency, to be used in the manufacture of a variety of psychoactive stimulants, including the so-called legal highs (or designer drugs).

www.interpol.int/Public/EnvironmentalCrime/Meetings/7thConference/Default.asp- info dated December 12, 2010.

An estimated 6,000 specimens of the tiger are living at large today; cf. B. Holyst, Kryminologia..., p. 434.

There are ca. 2,800 specimens living in Asia; www.traffic.org/trade (info dated July 11, 2010). 
than lip-service. It appears, not infrequently, that the interest expressed in valuable species of plants and animals is purely exploitive. What the rebel leaders would really like is to gain control of the lucrative ecotourism market to line their own coffers; the money being used to pay their troops, bribe corrupt officials and enlist the collaboration of government army commanders. A model example of such opportunist tendencies can be seen in the activities of General Laurent Nkunda, leader of the CNDP, who considered himself to be guardian of the mountain gorillas. It is nonetheless commonly known that his soldiers were responsible for numerous attacks on the habitats of these creatures as well for participation in illegal coal contraband which was progressively devastating the very areas in which these great apes live. ${ }^{35}$

\section{Madagascar: predatory activity of local criminal syndicates}

Madagascar, a country that is renowned for its endemic flora and fauna, serves as an example of how transnational businesses are expanding with the support of local criminal structures. The focus of interest to foreign investors in Madagascar, as well as of local timber moguls and the militias they support, is mahogany and rosewood, used in the manufacture of high quality furniture. Officially both species of tropical hardwood are subject to strict preservation controls. In reality, systematic clearing of the forests in which these noble species of tree are to be found goes unabated; rosewood forests in particular are exposed to extinction. Troubled by political conflicts, Madagascar attempted to improve its economic status via the export of rosewood but pressure exerted by international public opinion, led to reinstatement of a ban on trading this and other species of tropical hardwoods, a ban that had earlier been lifted. As a result the black market in rosewood blossomed and, as ecologists report, is continuing to develop at a disturbing pace. This situation exists because the country's authorities entangled themselves in several ethically questionable arrangements and are now either incapable of or unwilling to effectively deal with illegal logging gangs. Thus, illicit clearing has now been extended to include national park areas. Masoala National Park for example, acclaimed for its wide variety of rare plant and animal species, has been the subject of intense logging carried out by these gangs. One outcome of this mass-stripping of Madagascar's forests is progressive pauperization of the indigenous population. In quite large number, more-and-more people are leaving their traditional occupations of fishing, land cultivation and cattle breeding, to become involved in illicit clearing activities. As a result the nation is facing shortages of basic foodstuff and day-today commodities, with prices spiraling for those which remain available. Aside from 
destroying Madagascar's primeval forests, mass clearing on the scale described is also posing a serious threat to the many species of plant and animal life they support. Two particularly endangered species are the Leaf-tailed Gecko (Uroplatus henkeli) and the Angonoka or Ploughshare Tortoise (Astrochelys yniphora) both being endemic to Madagascar. The black market price for a single specimen of the Ploughshare Tortoise is circa USD 3,000. Another factor associated with mass-scale deforestation, apart from fostering poaching that is, is soil erosion. The question is to what end is this destruction? If one were to look at it in purely economic terms any gain from exploitation of the forests can only ever be short-term. Long-term it has little to offer. Even if all of the cleared land were given over to agriculture the value of crops produced would not begin to compensate for the annual loss of income derived from ecotourism, currently estimated at USD 390 million. It is this that permanent depletion of the forests is placing at risk. ${ }^{36}$

\section{Corruption and the activities of paramilitary organizations}

As emphasized earlier, the pillage of Africa's natural resources, especially its valuable species of tropical hardwoods, more often than not enjoys the support of corrupt local officials and wildlife guards who, in exchange for regular payment, turn a blind eye to this criminal activity. Soldiers and policeman at checkpoints are also bribed which allows illegally cut timber to pass freely on to the buyer without hindrance. Such corruption extends across the very top levels of both central and local government, which for all intents and purposes negates any serious attempt to fight this dangerous phenomenon. The scale of corruption which exists can be measured from the case of Honore Mashagiro, former commander of the national park guard and ICCN director for North Kivu. This official had for many years been involved in the illegal charcoal trade in association with paramilitary organizations, gaining hundreds of thousands of dollars a year for himself in the process. It is claimed that Mashagiro ordered the killing of a half-dozen or so mountain gorillas in order to place blame for the act on Paulin Ngobobo, the park warden responsible for safeguarding the gorillas but who was also attempting to expose and shut down charcoal activities in Virunga. At the suggestion of Mashagiro, Ngobobo was subsequently arrested and imprisoned. The gorilla massacre echoed loudly around the world, inspiring international reaction which in turn forced the government of the Democratic Republic of the Congo to take decisive action. As a result Mashagiro was arrested to face penal charges for the murder of the gorillas and his involvement in the charcoal trade. Ngobobo was reinstated in his former position. This affair 
clearly demonstrates the financial entanglements and arrangements that are woven by criminal structures engaged in wildlife crime. Suffice it to say that in 2006, legitimate gorilla tourism to Virunga brought in less than USD 300,000. By contrast, the Virunga charcoal trade was worth more than USD 30 million. To effectively fight these criminal structures, supported as they are by high-ranking military officers and paramilitary organizations, does not constitute an easy task and this is where the international community has a role to play. It needs to use its weight, particularly through ecological institutions and NGOs, in publicizing the pathological systems orientated towards plundering the world's flora and fauna and destroying their habitats. ${ }^{37}$

\section{Summary}

There is no doubt that in the coming years crimes against nature will grow to present major challenges to the international community, especially for those individuals and organizations charged with the responsibility of maintaining global security. Consequently, wildlife crime should become an area of penetrating research - particularly in the field of criminology - so that an optimal model for counteracting the pillage and destruction of valuable species of wildlife can be established. A peculiar role in this respect lays not just with the judicature and national park guard services but also with research centres tasked with identifying new phenomena in the domain of wildlife crime. As emphasized herein, one such phenomenon is the appropriation of natural resources by organized criminal structures who regard those resources as a potential source of funding for rebel or terrorist activity. The information presently available is far from complete and renders it necessary for the aforementioned entities to intensify collaboration. Equally such collaboration needs to be coordinated by an organization enjoying the confidence of the international community and which has a reputation for leadership and experience in combating wildlife crime.

Without doubt Interpol is one such entity suited to this task. The organization's wide-ranging interest in crime targeted at wildlife and its experience in coordinating multi-national law enforcement agencies to combat it, lend to its credibility as too does its ability to cooperate with other entities and initiatives dedicated to protecting the world's natural resources. Among them, the Conference of the Parties to the Convention on International Trade in Endangered Species of Wild Fauna and Flora (CITES), referred to as the Washington Convention, is definitely to be counted. The existing relationship between the Convention's Secretary and the Secretary General of Interpol, serves as a model example of effective cooperation. This opinion can be 
extended to undertakings carried out by Interpol in conjunction with other global entities, to name in particular: the UN Environmental Programme (UNEP); the Convention on Biological Diversity (CBD); ${ }^{38}$ the Convention on the Conservation of Migratory Species of Wild Animals (CMS); ${ }^{39}$ the Great Apes Survival Project (GRASP) ${ }^{40}$ and the International Tropical Timber Organization (ITTO). ${ }^{41}$ Credit must also be given to UNODC, for the part it has played on counteracting crimes against nature. It ought to be remarked that both Interpol and UNODC are signatories to the International Consortium on Combating Wildlife Crime (ICCWC).$^{42}$ One of the notable tasks of the latter is counteracting the use of valuable flora and fauna in financing armed conflicts and terrorism. Non-government organizations are important allies in this task as they monitor, on a continual basis, occurring threats in the area of natural environment protection. Representatives of "green" NGOs are also the greatest threat to poachers as they continually monitor the numbers of protected animal species, informing national park guards of anything they find wrong. Because of this, they too, often fall victim to poaching gangs. ${ }^{43}$

Among the many problems addressed by research centres, one that should become the subject of in-depth analysis is the corruption of officials of weak or bankrupt states. This needs to be given particular attention along with the sell-off of national natural resources made under so-called disgracing contracts, where state structures are transformed into criminal structures (criminalization of power) and where the involvement of international consortia exploiting the Earth's natural resources becomes tangled with paramilitary groups, militias and private military companies to pillage or destroy the habitats of valuable species of wildlife.

This article has attempted to demonstrate that armed conflicts, often assuming the form of tribal wars, pose the greatest threat to valuable areas of nature. Their source cannot simply be placed at the door of mutual prejudices with underlying tribal or religious differences, the true cause lays in poverty and lack of education. Consequently, without first putting thorough socio-economic reforms in place, solution of the various conflicts which prevail in certain areas of our planet (Chad, Somalia, Sudan/Darfur, South Sudan, Sri Lanka, Colombia, Palestine, et al -

38 CBD came into being in Rio-de-Janeiro as of June, 1992, with Poland ratifying it in 1996 (i.e. Journal of Laws 2002, No. 184, item 1532). The Convention is meant to protect biodiversity, balanced use of its elements, and fair and just distribution of benefits ensuing from use of genetic resources.

39 CMS, also called the Bonn Convention, was drawn up on June 23, 1979, in Bonn, former West Germany, with a view to provide protection to wild animals that, on migrating, crossed one or more state jurisdiction frontiers in their various life cycles (cf. JL 2003, No. 2, item 17).

40 The project is implemented under the aegis of the CITES Convention and provides for imposition of a complete ban on commercial trading in great apes and derivative products thereof.

41 ITTO was set up in 1986 under the auspices of the UN, with the view of monitoring undertakings associated with the protection of tropical forests.

42 See: W. Pływaczewski, Inicjatywy Międzynarodowe Organizacji Policji Kryminalnej - INTERPOL na rzecz ochrony dzikich gatunków zwierząt "Prokratura i Prawo" No. 10/2011.

43 W. Pływaczewski, Combating Organized Poaching in Africa..., p. 55. 
where poverty and deficit of education have been the main reasons for warfare and terrorism) is hardly to be expected.

This situation is often contributed to by the activities of large transnational corporations which specialize in the exploitation of natural wildlife resources and which, in the pursuit of profit, are prepared to plunder protected species of flora and fauna. Civil servants corrupted by these concerns, in turn organize private armies to protect their interests and those of their foreign paymaster. These transactions to appropriate natural resources and which are often convoluted, involve political figures, civil servants, members of the military, members of the police and at the foot of the ladder, national park guards, although their role is sometimes without option. Resulting from this uncontrolled plunder and destruction of areas opulent with valuable flora and fauna, poverty is expanding. This triggers subsequent social tensions which are a source of new conflicts and wars. In turn, this state of affairs can often cause weak countries - which may otherwise have formally declared their willingness to create democratic structures - to transform into classic dictatorships which thrive on the back of international consortia. The appropriation of natural resources by such organizations - especially of protected species of wildlife - does not just lead to poverty and political chaos. It also generates a sense of injustice and promotes willingness to seek revenge, which, in extreme cases, may encourage dissidents in local communities to resort to terrorism. The international community should thus be made well aware that the establishment of efficient mechanisms to control operations of great international concern, is an essential condition to ensure global order. As this article has attempted to prove, protection of the world's natural resources is its material guarantor. 


\section{ZORGANIZOWANY HANDEL CHRONIONYMI GATUNKAMI DZIKIEJ FAUNY I FLORY JAKO FORMA WSPIERANIA KONFLIKTÓW ZBROJNYCH I TERRORYZMU}

Artykuł stanowi pierwsze w polskiej literaturze kryminologicznej opracowanie na temat związków pomiędzy przestępczością przeciwko środowisku naturalne$\mathrm{mu}, \mathrm{w}$ tym chronionym gatunkom fauny i flory, a konfliktami zbrojnymi oraz terroryzmem. Autor przede wszystkim charakteryzuje poszczególne przejawy i formy tej przestępczości, ukazując ją na tle ogólnej problematyki dotyczącej ochrony przyrody oraz uwarunkowań społeczno-politycznych w tzw. zapalnych regionach naszego globu. Zawarte w niniejszym opracowaniu uwagi i spostrzeżenia dotyczą najbardziej zagrożonych konfliktami zbrojnymi obszarów naszej planety (Afryka, Azja południowo-wschodnia, Ameryka Południowa). Jako modelowy przykład grabieży i niszczenia cennej przyrody autor wskazuje objęte walkami zbrojnymi wschodnie pogranicze Demokratycznej Republiki Konga a także nękane wewnętrznymi konfliktami cenne przyrodniczo obszary Madagaskaru. Uważa on jednocześnie, że w najbliższych latach relacje pomiędzy zorganizowanymi strukturami przestępczymi zajmującymi się grabieżą przyrody a organizacjami destrukcyjnymi i terrorystycznymi będą systematycznie się zaciaśniać, stanowiąc tym samym poważne zagrożenie dla globalnego ładu. W ramach działań zapobiegawczych autor postuluje zintensyfikowanie międzynarodowej współpracy na rzecz ochrony najbardziej zagrożonych obszarów ziemi. Pośród licznych podmiotów, które stanowią już dziś ważne ogniwo $\mathrm{w}$ walce $\mathrm{z}$ zorganizowaną przestępczością godzącą $\mathrm{w}$ naturalne zasoby przyrodnicze (m.in. Międzynarodowa Organizacja Policji Kryminalnej - INTERPOL, Biuro Organizacji Narodów Zjednoczonych ds. Narkotyków i Przestępczości oraz Sekretariat Konferencji CITES), autor wskazuje także organizacje pozarządowe, uznając je za istotny element działań proekologicznych. W zakończeniu opracowania podkreślono potrzebę niwelowania dysproporcji społecznych i szerzenia edukacji na obszarach dotkniętych ubóstwem, uznając te dwa elementy za podstawę przyszłego modelu przeciwdziałania zjawiskom destrukcyjnym na świecie, w tym zamachom na światowe dziedzictwo przyrody.

Key words:

Organized crime, wildlife crime, armed conflicts, illegal exploitation of primeval forest areas 